\title{
Минерагеническое районирование керамических глин Воронежской антеклизы
}

\author{
(C2020 А. В. Крайнов ${ }^{\varpi}$, С. В. Мануковский \\ ${ }^{1}$ Воронежский государственный университет, \\ Университетская пл., 1, 394018 Воронеж, Российская федерация
}

\begin{abstract}
Аннотация
Введение: На территории Центрально-Черноземного района керамические глины являются ценным и одновременно дефицитным сырьем. Они приурочены к отложениям мамонской толщи верхнего девона, аптского яруса нижнего мела, свитам: киевской эоцена, берекской олигоцена, шапкинской миоцена и усманской плиоцена. Глины разновозрастных месторождений отличаются по условиям образования, вещественному составу и качеству. Поэтому вопрос о минерагеническом районировании керамических глин является актуальным.

Методика: Решение задач по минерагеническому районированию определило использование комплекса методик. Были проведены полевые исследования, камеральные построения фациальных карт и разрезов, лабораторные и технологические испытания. На основании комплексного анализа полученных данных выделены таксоны для регионального минерагенического районирования в рангах: минерагенические (рудные) зоны, районы и узлы. В процессе проведения работ задокументирован и опробован керн более 50 скважин, описаны и опробованы породы свыше 90 точек наблюдений (обнажения и карьеры) в пределах Воронежской, Курской, Липецкой, Орловской областей. Подготовлены пробы, с помощью прецизионных методов (дифрактометрический и электронно-микроскопический) изучен минеральный и химический составы глин около 200 образцов. Результаты и обсуждение: Керамические глины мамонской толщи формировались в пролювиально-делювиальных и озерно-болотных фациях. Для них выделена Мамонская минерагеническая зона, которая включает в себя Павловск-Калачский район, а в нем перспективная Воробьевская площадь. Керамические глины апта приурочены к озерно-болотным и лагунно-морским обстановкам. Ценные огнеупорные разности образовались на суше в результате «проточного» диагенеза, тугоплавкие - при осадконакоплении. Различия в условиях формирования повлекли за собой отличия в вещественном составе и качестве глинистого сырья. Это позволило выделить Воронежский и Курско-Елецкий минерагенические районы. Они входят в состав МалоархангельскВоронежской минерагенической зоны. Воронежский минерагенический район соответствует распространению континентальных фаций, Курско-Елецкий - лагунно-морских. Для керамических глин кайнозоя минерагеническое районирование не проводилось, т.к. это сырье невысокого качества, месторождения рассредоточены по территории и площади развития фаций незначительны.

Bblвoдbl: впервые методом близкой аналогии выделены минерагенические таксоны для разновозрастных керамических глин, подсчитаны прогнозные ресурсы. Суммарно по категории $\mathrm{P}_{3}$ они составили 51,1 млн т
\end{abstract}

Ключевые слова: керамические глины, минерагенические зона, район, узел, мамонская толща, аптский ярус, кайнозой.

Контент доступен под лицензией Creative Commons Attribution 4.0 License.

\footnotetext{
${ }^{凶}$ Крайнов Алексей Владимирович, E-mail: aleksey_vsu_geo@mail.ru
} 
Для цичтирования: Крайнов А. В., Мануковский С. В., Минерагеническое районирование керамических глин Воронежской антеклизы // Вестник Воронежского государственного университета. Серия: Геология. 2020. №1. C. 66-77. DOI: https://doi.org/10.17308/ geology.2020.1/2515

\section{Введение}

Керамические глины являются одним из самых важных и ценных видов сырья на территории Центрально-Черноземного экономического региона, однако, минерагеническому районированию керамических глин не уделено должного внимания. Так, для листа масштаба 1:1 000000 M-37 (Воронеж) (рис. 1) выделяется лишь Воронежский минерагенический район, в то же время на листе N-37 (Москва), несмотря на наличие в его пределах крупных месторождений, не выделены районы развития керамических глин. Также не выделены более крупные таксоны минерагенические зоны.

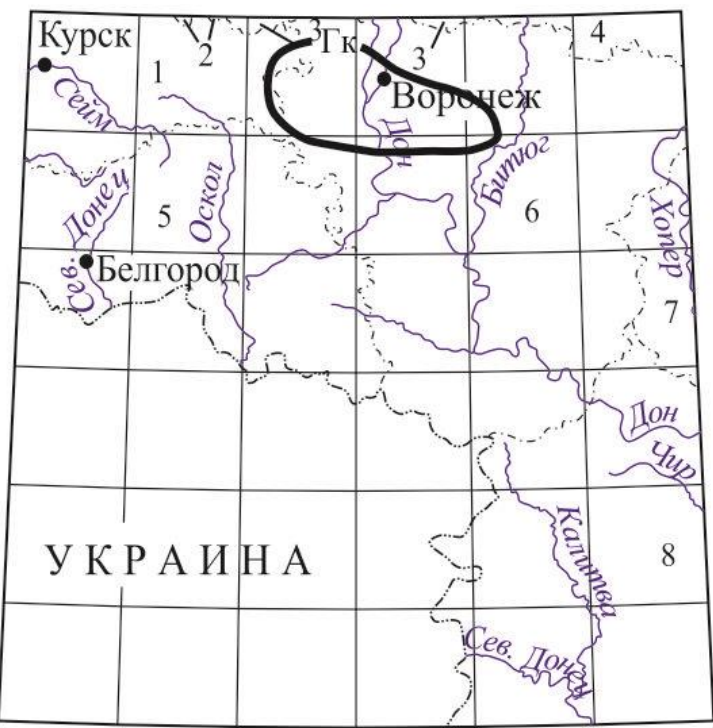

масштаб 1:10 000000

\section{РОССИЯ}

1 Курская обл.

2 Орловская обл.

3 Липецкая обл.

4 Тамбовская обл.
5 Белгородская обл.

6 Воронежская обл.

7 Волгоградская обл. 8 Ростовская обл.

Рис. 1. Выкопировка из схемы минерагенического районирования листа М-37 (Воронеж). Схема административного деления.

[Fig. 1. The mineralogical zoning sheet M-37 (Voronezh). Administrative division.]

Воронежский минерагенический район, согласно предлагаемому районированию, приурочен к распространению песчано-глинистых отложений аптского яруса нижнего мела и объединяет Латненское месторождение огнеупорных глин и Большекарповское тугоплавких, однако, при минерагеническом районировании не были учтены особенности генезиса аптских глин.

Помимо аптских, месторождения и проявления керамических глин известны в отложениях киевской (эоцен), берекской (верхний олигоцен), шапкинской (нижний миоцен), усманской (нижний плиоцен) свит. С киевскими образованиями связано Сергиевское месторождение и Горшеченское проявление низкокачественных керамических глин, с берекскими - крупное, но некондиционное, Россошанское месторождение, с шапкинскими - мелкие Краснопольское, Колотиловское, Краснояружское, Новенькое, с усманскими - среднее по запасам Байгоровское. Государственным балансом запасов учтены Краснояружское и Шрамовское месторождения, которые находятся в нераспределенном фонде недр [1].

Большой интерес представляет мамонская песчано-каолиновая толща (ПКТ) верхнего девона, развитая на юге Воронежской антеклизы. С ней многие авторы связывали возможности нахождения месторождений каолинов, проводились поисковоразведочные работы на прогнозируемых участках, но только в 2017 г. было разведано первое месторождение вторичных каолинов Козынка, которые относится к керамическому сырью. Это подтвердило перспективность ПКТ на подобные месторождения и необходимость в более обоснованном прогнозе на них.

Эта информация, ранее проведенные исследования генезиса аптских глин [2-5], а также выделенные в результате работ по ГДП-200 [6] проявления керамических глин позволяют внести существенные коррективы в минерагеническое районирование исследуемой территории.

\section{Методика}

Минерагеническое районирование основывается на анализе рудоконтролирующих факторов и поисковых признаков полезных ископаемых. Среди основных факторов, определяющих становление месторождений в осадочном чехле Воронежской антеклизы, выделяются общие, создающие предпосылки для их формирования и частные, определяющие вид гипергенных полезных ископаемых. В первую группу входят тектонический, климатический, стратиграфический и эволюционный факторы. Ко второй группе отнесены палеогеоморфологический, литологический, гидродинамический, органический, диагенетический, эпигенетический, вулканогенный и гидротермальный [7]. По нашим представлениям, применительно к месторождениям керамических глин, в первую группу входят климатический, структурно-тектонический, стратиграфический и палеогеоморфологический факторы. Вторая группа включает фациальный и диагенетический факторы.

В региональном плане климатический, структурно-тектонический, стратиграфический и геоморфологический факторы определяют условия локализации в регионе месторождений глинистого сырья в целом. Локальные факторы (фациальный и диагенетический) 
ответственны за размещение, генезис и вещественный состав огнеупорных и керамических глин рассматриваемой территории.

Решение задач по минерагеническому районированию определило использование комплекса методик. Их можно разделить на четыре группы. Первая включает методы проведения полевых исследований с отбором фактического материала, вторая - построение фациальных карт и разрезов. Третья группа методов использовалась для исследования вещественного состава глин, четвертая для изучения технологических свойств глин.

Сбор фактического материала производился путем выполнения поисковых маршрутов, бурения скважин с последующим опробованием. При этом производилась тщательная документация горных выработок.

При камеральных исследованиях проводилось составление фациальных карт, которое состоит из нескольких этапов. На первом этапе строились сопоставительные колонки, на которые выносились фациальные признаки пород: структурно-текстурные, минералогические остатки флоры и фауны и т.д. Следующий этап заключается в построении фациальных разрезов. На них выносятся границы фациальных обстановок и литологические типы пород данных обстановок. Индекс литологического типа характеризует условия формирования осадков: I - глубоководно-морские (на изученной территории не выделяются), II - мелководно-морские, III - прибрежно-морские, IV - переходные (лагунно-морские), V - континентальные. Огромное влияние на формирование тех или иных фаций оказывает гидродинамический режим, обозначаемый буквами. Литологический состав пород на сопоставительных колонках, разрезах и картах показан соответствующим знаком.

При минерагенических построениях использовался ряд аналитических методов. Главные из них: гранулометрический (устанавливалась засоренность глинистых пород), рентгеноструктурный (определение минерального состава), химический (определение сортов глин по содержанию $\mathrm{Al}_{2} \mathrm{O}_{3}, \mathrm{TiO}_{2}, \mathrm{Fe}_{2} \mathrm{O}_{3}$ ), электронномикроскопический (определения морфологии глинистых частиц) анализы.

При проведении технологических испытаний особое внимание уделялось показателям огнеупорности и интервалу спекаемости. Дополнительно изучались пластичность, степень белизны, цвет черепка после обжига, водопоглащение, связанность, прочностные характеристики. Авторы пытались увязать зависимость керамических свойств от вещественного состава.

При минерагенических построениях лишь месторождения выделяются на основании прямых геологогеофизических и геолого-геохимических признаков, все остальные таксоны - на основе концепций, опирающихся на представления о тектоническом положении объектов, их формационном составе и генезисе. Базовыми таксонами для регионального минерагенического районирования являются: минерагенические (рудные) зоны, районы и узлы. Первые отве- чают структурно-формационным зонам и выделяются на основании: анализа ряда геологических и ассоциирующих с ними рудных формаций; геотектонического положения этих рядов; фациальной принадлежности геологических образований. Внутри минерагенической зоны определяются районы - продуктивная часть зоны. Они рассматриваются на уровне рудной формации. Главные геологические признаки для выделения рудных районов - рудоносные формации и внутриформационные факторы, характеризующие предполагаемый источник рудного вещества, пути его миграции и участки локализации. Минерагенические узлы входят в состав районов, имеют площадь более 100 км $^{2}$ и представляют собой относительно изометричные площади на фоне слабоминерализованных или безрудных площадей [8].

Для минерагенических узлов были подсчитаны прогнозные ресурсы по категории $\mathrm{P}_{3}$. Они учитывают потенциальную возможность открытия месторождения определенного промышленного типа на основании благоприятных геологических палеогеографических предпосылок [8]. Подсчет осуществлялся методом «близкой» аналогии на основе удельной продуктивности эталонного объекта, по формуле:

$$
\mathrm{G}_{\mathrm{n}}=\mathrm{P}_{\mathrm{n}} * \mathrm{~S}_{\mathrm{n}} * \mathrm{k}-\left(\mathrm{A}+\mathrm{B}+\mathrm{C}_{1}\right),
$$

где: $\mathrm{G}_{\mathrm{n}}$ - прогнозные ресурсы, т; $\mathrm{P}_{\mathrm{n}}-$ удельная продуктивность эталонной площади, т/км ${ }^{2} ; \mathrm{T} ; \mathrm{S}_{\mathrm{n}}-$ площадь прогнозируемого узла, $\mathrm{m}^{2} ; \mathrm{k}$ - коэффициент подобия; $\left(\mathrm{A}+\mathrm{B}+\mathrm{C}_{1}\right)$ - суммарные запасы попадающих в площадь рудного узла месторождений [9].

\section{Обсуждение результатов}

Керамические глины мамонской толщи. С ceредины XX века ПКТ рассматривалась как перспективная для поисков в ней месторождений керамических глин. Начиная с этого времени, активно проводились поисково-разведочные работы, выделялись перспективные участки, которые разбуривались разными количествами скважин, но месторождений каолинов не выявлено. При этом подсчитывались прогнозные ресурсы каолинов в десятки миллионов тонн. В качестве попутно-добываемого сырья принимались кварцевые каолинсодержащие и относительно чистые пески в качестве стройматериалов, прогнозные ресурсы которых на порядок выше, чем каолинов. В работе [10] выделены прогнозные участки для постановки поисковоразведочных работ на каолины (4 участка) и кварцевые пески (6 участков). Постепенно пришло осознание того, что кварцевые пески сами по себе или попутно добываемые, представляют не менее ценное, чем каолины, полезное ископаемое как стекольное, формовочное и строительное сырьё. Вместе с тем содержащие каолинит разности песков могут служить источником получения обогащенного каолина. В 2017 г. в пределах листа М-37-XVII (Павловск) выявлено месторождение вторичных каолинов Козынка [11]. 
После выявления этого месторождения, нами выделена Мамонская минерагеническая зона по границе распространения ПКТ. Территориально она приурочена к югу Воронежской области, частично, к востоку Белгородской, северу Ростовской и северозападу Волгоградской областей (рис. 2). Общая пло-

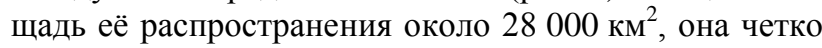
разделяется на 3 участка: Западный, Центральный и

\section{Восточный.}

Западный участок протягивается от границы Курской и Белгородской областей до г. Павловска на 280 км при ширине полосы от 25 до 60 км. Этот участок наименее перспективен на огнеупорное сырье, ввиду резкого преобладания обломочных пород и большой мощности перекрывающих отложений (от 40 до первых сотен метров).

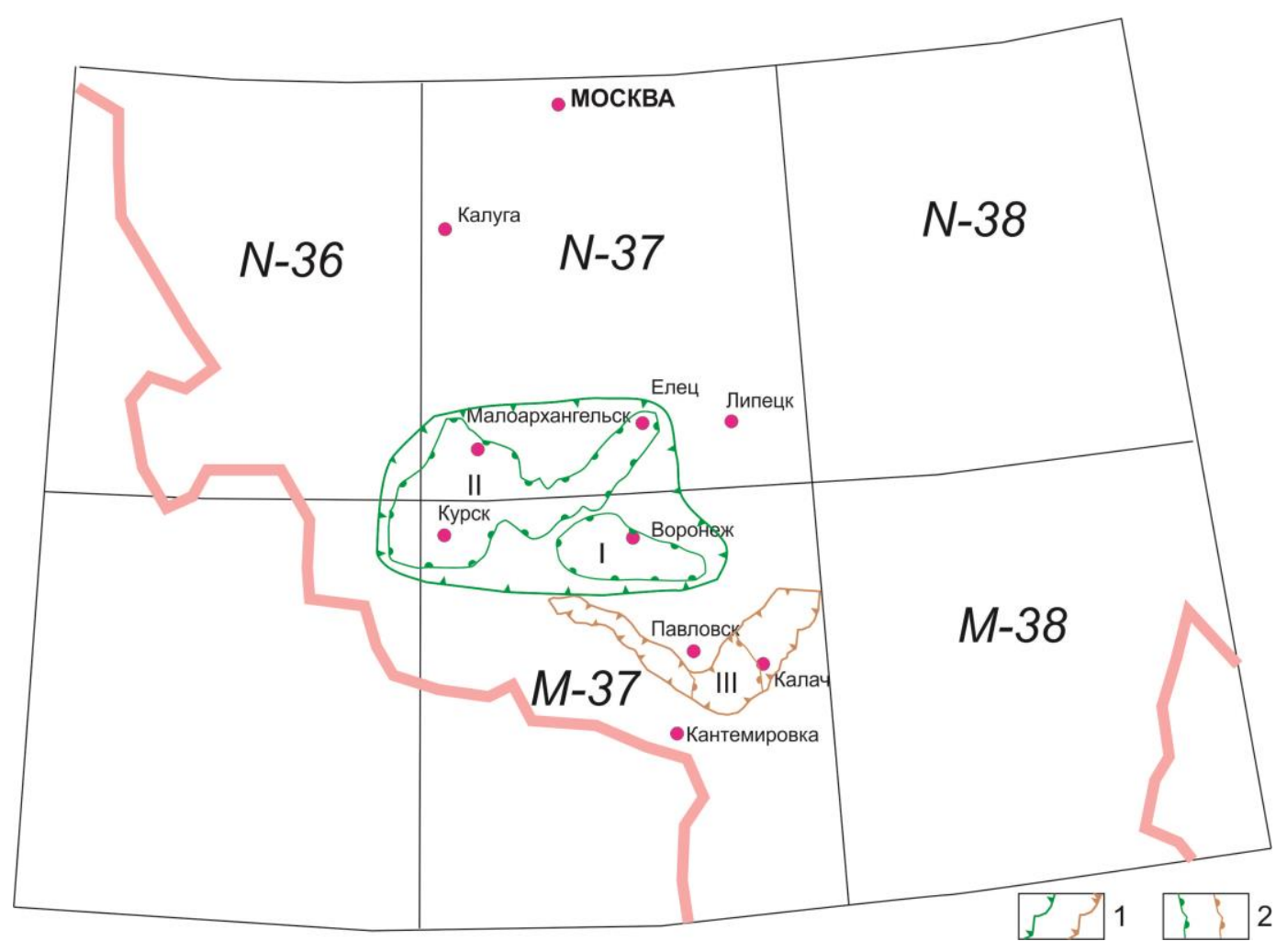

Рис. 2. Предлагаемая схема минерагенического районирования для керамических глин листов N-37, М-37. Условные обозначения: 1 - зеленым - Малоархангельск-Воронежская минерагеническая зона; коричневым - Мамонская минерагеническая зона; 2 - минерагенические районы: $I$ - Воронежский, $I I$ - Курско-Елецкий, $I I I$ - Павловск-Калачский.

[Fig. 2. The proposed scheme of mineralogical zoning for ceramic clay sheets N-37, M-37. Legend: $1-$ green - Maloarkhangelsk Voronezh mineralogenic zone; brown - Mamon mineralogenic zone; 2 - mineralogical regions: $I$ - Voronezh, II- Kursk-Yelets, III - Pavlovsk-Kalach].

Центральный участок располагается к востоку от долготы г. Павловска до г. Калач. Его длина и ширина порядка 60 км каждая. Восточный участок прослеживается восточнее долготы г. Калач. Именно по границам распространения центрального участка выделен Павловск-Калачский минерагенический район. Основанием для его выделения послужило наличие месторождения, а также выявленные на фациальных картах континентальные фации, благоприятные для формирования месторождений керамических глин. Здесь мамонская песчано-каолиновая толща содержит относительно мощные пласты глин и каолинитсодержащих песков и залегает неглубоко. При проведении работ по ГДП-200 листа М-37-XI (Бобров) в пределах Павловск-Калачского минерагенического района выявлена перспективная на глины керамические и огнеупорные Воробьевская площадь (ВП) (рис. 3). Основанием для выделения пер- спективной площади послужило наличие Воробьевского проявления и континентальных фаций (озерноболотных и аллювиальных пойменно-старичных), благоприятных для формирования месторождений керамических глин.

Для перспективной ВП на глины керамические и огнеупорные подсчитаны прогнозные ресурсы по категории $\mathrm{P}_{3}$. Запасы эталонного месторождения Козынка по категории $\mathrm{C}_{1}+\mathrm{C}_{2} 10$ млн т, прогнозные ресурсы по категории $\mathrm{P}_{1}-6.64$ млн т, приведенные к условным запасам категории $\mathrm{C}_{2}-3.32$ млн т. Удельная продуктивность эталонного объекта составляет $\quad \mathrm{P}_{\mathrm{n}}=13.32 / 2.2=6.66 \mathrm{млн} \mathrm{т/км².} \mathrm{Удельная}$ продуктивность, приведенная к рудному узлу: 6.66 млн $\mathrm{T} / \mathrm{\kappa м}^{2} * 0.2 * 0.2=0.266$ млн т/км ${ }^{2}$. Площадь перспективной ВП составляет 147 км$^{2}$, коэффициент подобия $\mathrm{k}=0.2$. 

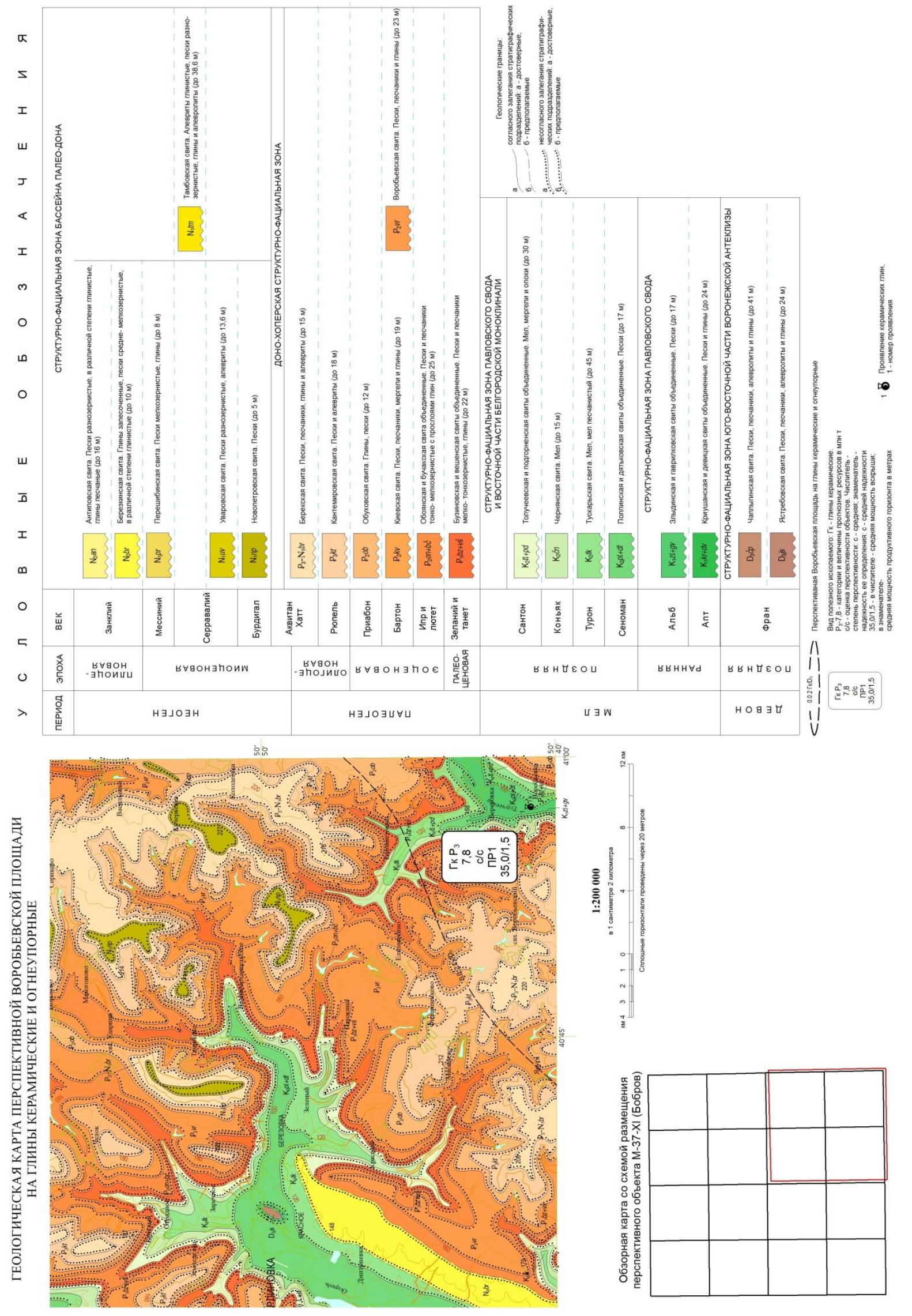
$\mathrm{G}_{\mathrm{n}}=0.266$ млн т $/ \mathrm{\kappa м}^{2} * 147 * 0.2=7.8$ млн т. Принимаем $\mathrm{G}_{\mathrm{n}}=7.8$ млн т.

Западный участок располагается к востоку от долготы г. Калач. В пределах участка в ПКТ появляются переходные и морские фации, снижается доля континентальных отложений, поэтому западный участок мало перспективен на обнаружение месторождений.

Керамические глины аптского яруса. Ранее проведенные по ним исследования, а также полученные данные при ГДП-200 листов М-37-I (Курск), М37-II (Кшень), M-37-III (Касторное), N-37-XXXIII (Елец), позволяют внести изменения в схему минерагенического районирования для листов масштаба 1:1 000000 N-37 и М-37 (рис. 2).

Малоархангельск-Воронежская минерагеническая зона проходит через северную и северозападную части листа М-37 (Воронеж), южную и югозападную части листа N-37 (Москва), и захватывает юго-восточную и северо-восточную оконечности листов N-36 (Смоленск), и М-36 (Киев) соответственно. Зона выделена по суммарному распространению континентальных и лагунно-морских фаций апта, в которых происходило формирование керамических глин. В пределах этой минерагенической зоны нами выделено 2 района: Воронежский и Курско-Елечкий.

Воронежский рудный район расположен в северной части листа М-37 и объединяет в себе 2 крупных месторождения огнеупорных глин: Латненское и Криушанское, а также ряд проявлений, выявленных при ГДП-200 (рис. 4). Его контуры приурочены к границам распространения фаций высокой и низкой аллювиальных равнин. Как показано в ранее проведенных работах [2-5], именно в этих обстановках происходило формирование огнеупорных разновидностей керамических глин. Почти мономинеральный каолинитовый состав огнеупорных глин Воронежского района обусловлен процессами «проточного» диагенеза [12] полиминеральных глин иллиткаолинитового состава, поступающих в седиментационный бассейн с юга территории при размыве мамонской толщи. Эти процессы разложения и выноса неустойчивых компонентов (щелочей, щелочноземельных элементов), обогащение глинистого осадка оксидами алюминия и титана вплоть до появления гиббсита происходили на аллювиальной равнине в старичных болотах, богатых органикой. При «проточном» диагенезе $\mathrm{Fe}$ из неподвижной трехвалентной формы переводилось в подвижную двухвалентную и мигрировало из глин, улучшая их качества

В пределах Воронежского минерагенического района выделено четыре минерагенических узла развития

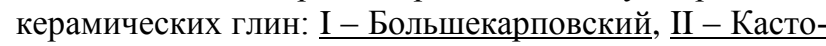
ренский; III - Старо-Ведугский, IV - Латненский (рис. 4). Подсчитаные прогнозные ресурсы по трем рудным узлам по категории $\mathrm{P}_{3}$ в сумме составляют 26.4 млн т.

Курско-Елеикий минерагенический район проходит через северную и северо-западную части листа М-37 (Воронеж), южную и юго-западную части листа N-37
(Москва), и захватывает юго-восточную и северовосточную оконечности листов N-36 (Смоленск), и М36 (Киев) соответственно. Он объединяет в себе Лукошкинское, Чибисовское, Большекарповское.

Малоархангельское месторождение тугоплавких глин и ряд проявлений, выделено при ГДП-200 листа M-37-XXXIII (Елец). Его контуры совпадают с границами распространения лагунно-морских фаций, в которых происходило формирование тугоплавких разновидностей керамических глин. Они имеют иллиткаолинитовый состав, образовались за счет размыва КВ и продуктов их переотложения в источниках сноса. Состав глин выдержан, меняется, лишь соотношение глинистой и песчаной компонент. В благоприятных для осаждения глинистых илов обстановках лагунноморской зоны сформировалось большинство месторождений и проявлений керамических глин. При этом дозревания осадка не происходило. Преобразования каолинита в щелочной лагунно-морской среде связаны с дроблением его кристаллов и некоторым разупорядочиванием структуры. Это и определяет отличие Воронежского минерагенического района от КурскоЕлецкого: в пределах первого формировались качественные огнеупорные разновидности керамических глин за счет дозревание осадка; в пределах второго существенных преобразований не происходило, здесь образовывались тугоплавкие разновидности керамических глин при одном источнике сноса.

В пределах листа N-37-XXXIII (Елец) в составе Курско-Елечкого минерагенического района выделяется 3 объекта -1 рудное поле: потенциальное Афанасьевское (2.1.0.1) и 2 рудных узла: ЛукошкинскоКаменский (2.1.1), и потенциальный Сновинский (2.1.2) (рис. 5). В пределах Лукошкинско-Каменского рудного узла выделено Чибисовско-Каменское рудное поле (2.1.1.1). Оно объединяет три средних месторождения (Чибисовское, Лукошкинское и Черкасские Дворики) и одно проявление (Соколье). В контуре Лукошкинско-Каменского рудного узла (2.1.1) выявлено 4 проявления керамических глин: Екатериновское, Зыбинковское, Каменское, Борковское; в границах потенциального Сновинского рудного узла (2.1.2) выделено два проявления керамических глин: Дегтевое, Сцепновское; потенциального Афанасьевского рудного поля (2.1.0.1) - одно проявление керамических глин - Вязовое.

На исследованной территории подсчитаны прогнозные ресурсы керамических глин по категории $\mathrm{P}_{3}$ для Лукошкинско-Каменского (9.0 млн т) и потенциального Сновинского (7.9 млн т) рудных узлов. В качестве эталонного объекта при подсчетах выбрано Чибисовско-Лукошкинского рудное, удельная продуктивность которого рассчитывалась путем деления суммарных запасов и прогнозных ресурсов Лукошкинского и Чибисовского месторождений на площадь рудного поля:

$\mathrm{P}_{\mathrm{n}}=(13923+8449) / 100=223.72$ тыс. $\mathrm{T} / \mathrm{\kappa м}^{2}$

Тогда для рудного узла удельная продуктивность: 

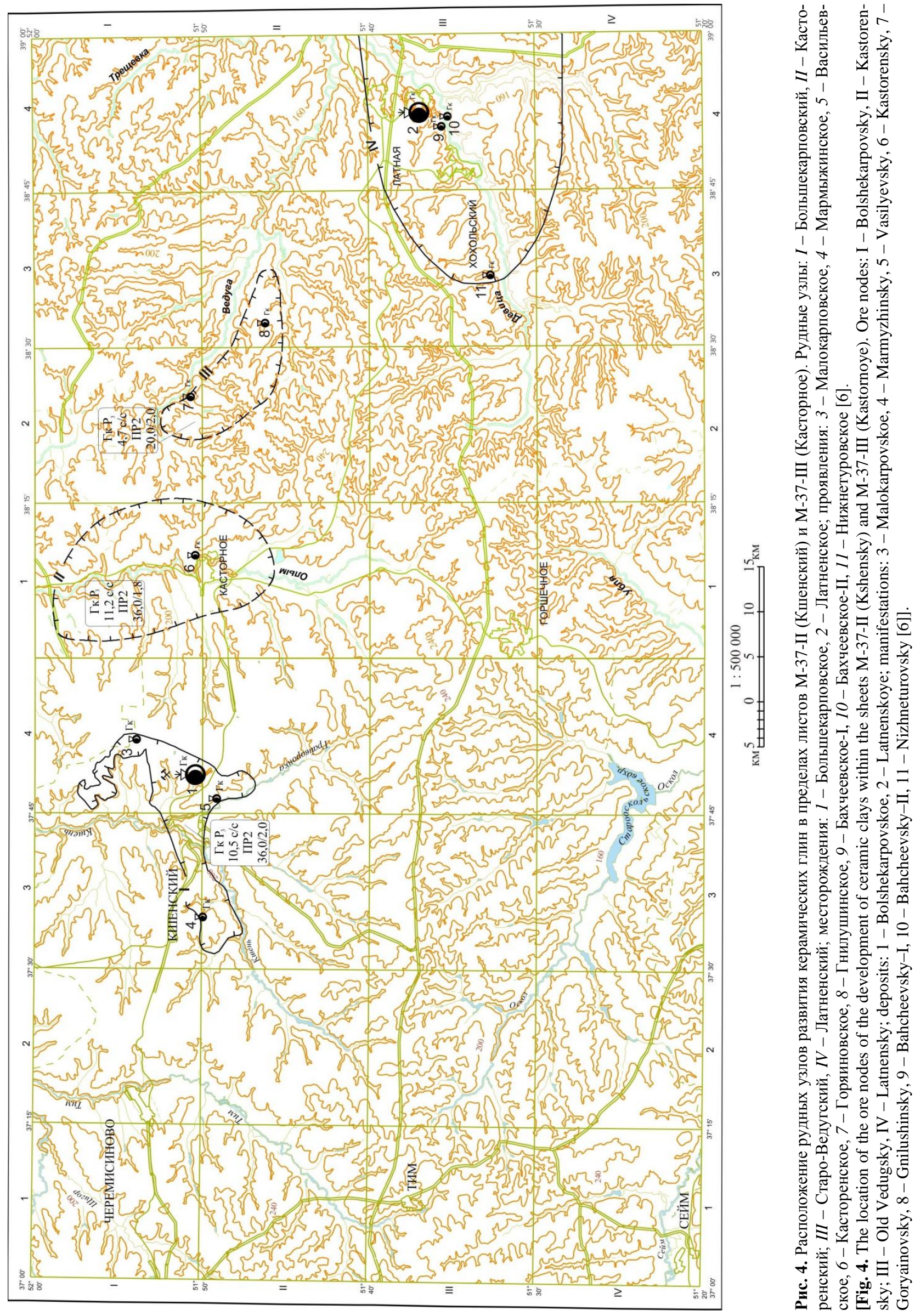


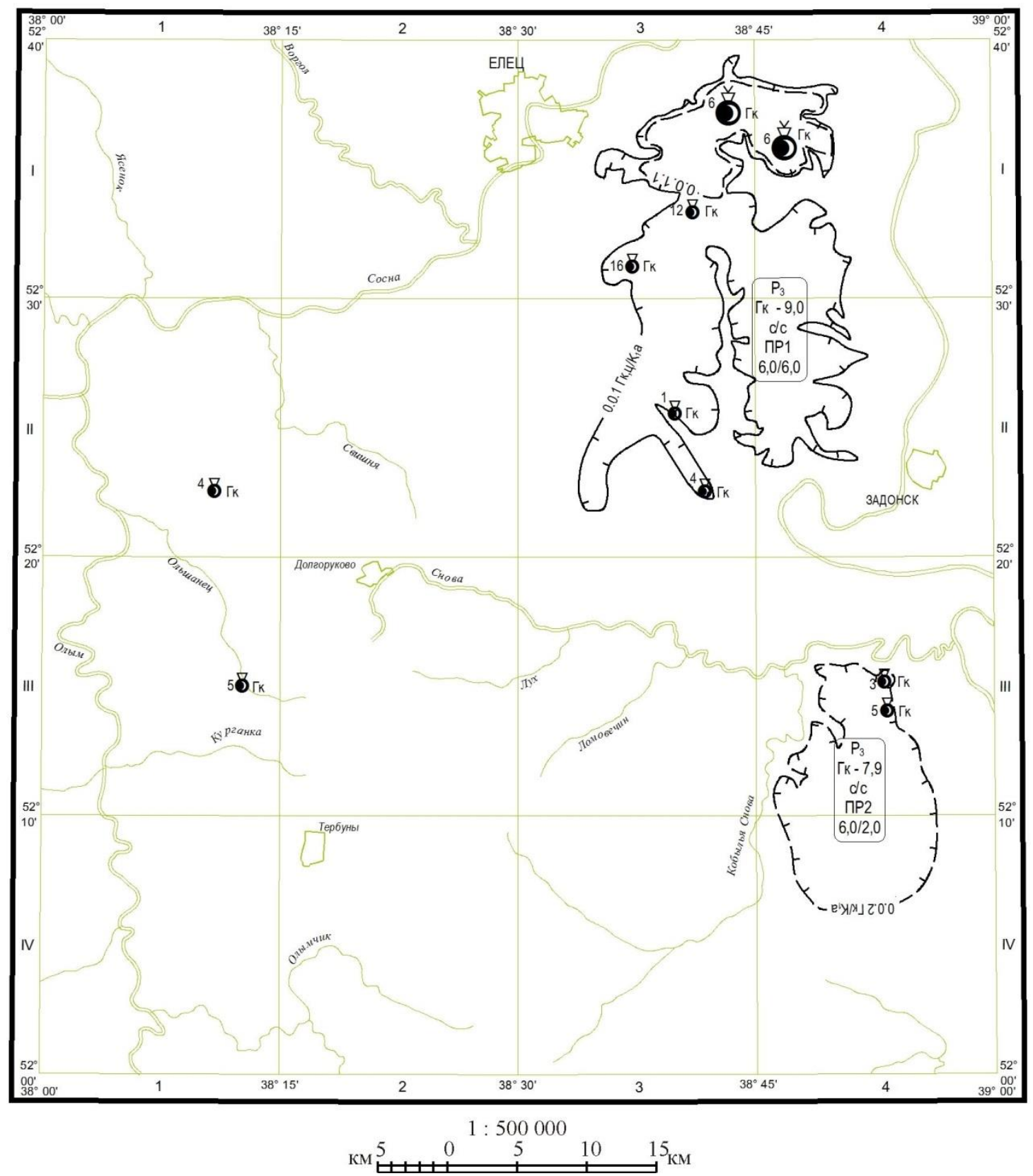

Рис. 5. Расположение рудных узлов развития керамических глин в пределах листа М-37-ХХХІІІ (Елец). Рудные поля: 2.1.0.1 - потенциальное Афанасьевское; 2.1.1.1 - Чибисовско-Каменское рудное поле. Рудные узлы: 2.1.1 - ЛукошкинскоКаменский; 2.1.2 - потенциальный Сновинский.

[Fig. 5. The location of the ore nodes of the development of ceramic clays within the sheet M-37-XXXIII (Elets). Ore fields: 2.1.0.1 - potential Afanasyevsky; 2.1.1.1 - Chibisovsk-Kamensky ore field. Ore nodes: 2.1.1 - Lukoshkinsko-Kamensky; 2.1.2 - potential Snovinsky].

$\mathrm{P}_{\mathrm{n}}=223.72$ тыс. $\mathrm{T} / \mathrm{\kappa м}^{2} * 0.5=111.86$ тыс. $\mathrm{т/км}{ }^{2}$.

Лукошкинско-Каменский минерагенический узел: $\mathrm{S}_{\mathrm{n}}=351$ км$^{2}, \mathrm{k}=0,8 . \mathrm{G}_{\mathrm{n}}=111.86$ тыс. т/км ${ }^{2} * 351 * 0.8-$ $(13923+8449)=9038.29$ тыс. $т$ или $\mathrm{G}_{\mathrm{n}}=9,0$ млн т

Прогнозируемый Сновинский минерагенический узел: $\mathrm{S}_{\mathrm{n}}=141 \quad \mathrm{\kappa м}^{2}, \quad \mathrm{k}=0,5 . \quad \mathrm{G}_{\mathrm{n}}=111860 \mathrm{~T} / \mathrm{\kappa м}^{2} * 141 * 0.5=$ 7886130 т. Принимаем $\mathrm{G}_{\mathrm{n}}=7.9$ млн т.

Керамические глины кайнозоя. В кайнозое установлены четыре стратиграфических уровня образования керамических глин, по два в палеогене и неогене. В палеогене это киевский (средний эоцен) и бе- рекский (верхний олигоцен) уровни, в неогене - шапкинский (нижний миоцен) и усманский (нижний плиоцен) (рис. 6). К первому уровню приурочено Сергиевское месторождение, Горшеченское проявление керамических глин, ко второму - Шрамовское (Россошанское), к третьему - Краснояружское, Краснопольское, Колотиловское и другие, к четвертому Байгоровское месторождения

В киевское время формирование керамических глин происходило в мелководно-морских условиях $[14,15]$ при размыве аптских и палеозойских каоли- 
нитсодержащих пород. Мелководно-морские фации неблагоприятны для формирования керамических глин, так как каолинит - главный минерал, определяющий их свойства не устойчив в щелочной морской среде. Это подтверждается дифрактограммами, на которых содержания каолинита, смектита и иллита примерно одинаковые. Поэтому киевские отложения наименее перспективные из рассматриваемых для выявления в них месторождений керамичеких глин.

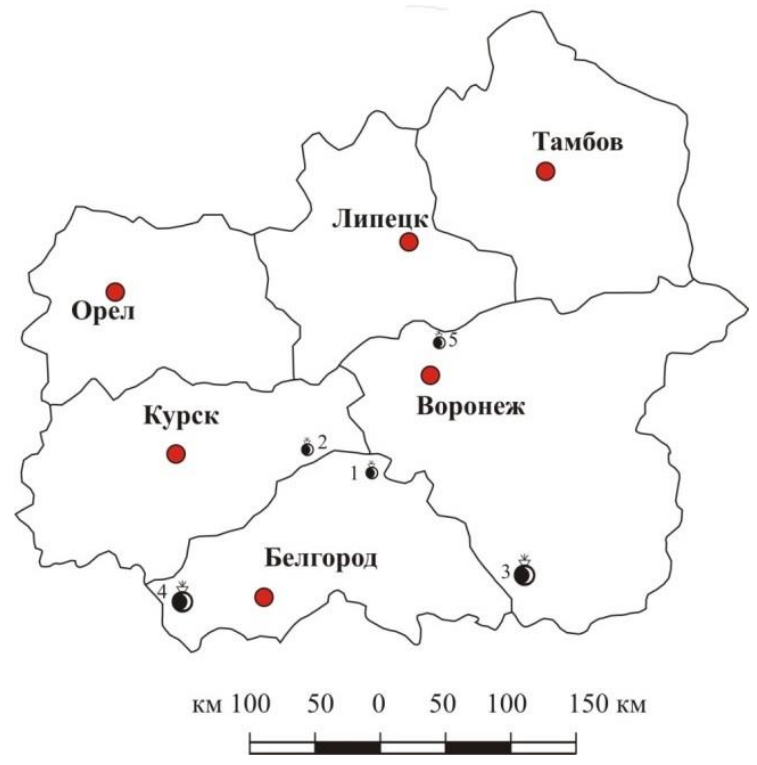

Рис. 6. Схема расположения кайнозойских месторождений и проявлений керамических глин Центрально-Черноземного района: 1 - Сергиевское, 2 - Горшеченское, 3 - Шрамовское (Россошанское), 4 - Краснояружское, 5 - Байгоровское [13].

[Fig. 6. The layout of the Cenozoic deposits and the manifestations of ceramic clays of the Central Black Earth region: 1 Sergievskoe, 2 - Gorshechenskoe, 3 - Shramovskoe (Rossoshanskoe), 4 - Krasnoyruzhskoe, 5 - Baygorovskoe [13]].

Миоченовые тугоплавкие глины образовались в озеровидных старичных бассейнах выровненной аллювиальной равнины в перстративную фазу накопления аллювия [16]. Их разрез сходен с перевернутым каолиновым профилем выветривания, когда в нижней части первого залегают каолиновые глины, а в верхней - полиминеральные. В глинах новопетровской свиты встречены вермикулярные кристаллы каолинита, что может быть свидетельством проточного диагенеза [4]. Следовательно, в озерно-болотных условиях происходило дозревание глинистого осадка, поэтому отложения новопетровской свиты миоцена наиболее перспективны для наращивания минерально-сырьевой базы керамических глин.

В плиоценовое время формирование керамических глин байгоровского типа происходило в пойменной фации констративной фазы накопления долинного аллювия $[17,18]$. При этом наиболее мощные глинистые толщи накапливались между локальными поднятиями или перед ними. Источником сноса для каолинита, служили каолинитовые глины из аллювиальной толщи апта, развитой северо-западней месторождения и размывающейся притоками крупной неогеновой реки. Вместе с тем, учитывая значительную мощность аллювия усманской свиты, подвешенность слоев глин в ней, можно предполагать наличие процессов проточного диагенеза, сходными с таковыми в озерноболотных условиях аптского времени $[4,5]$, приводящих к повышению содержания каолинита.

Следовательно, глины плиоцена наиболее перспективны в качестве керамического сырья. По мнению Г. В. Холмового [16-18] наиболее перспективны для поисков тугоплавких глин прибортовые зоны долин достаточно крупных рек со слабо констративным аллювием, в области питания которого эродировались глинистые породы.

Технологические свойства можно прогнозировать после проведения полевых и лабораторных исследований вещественного состава глин. Для керамических глин следует выбирать участки с минимальным содержанием монтмориллонита в их составе. Различные добавки могут перевести рассматриваемые керамические глины в более высокие сорта.

При проведении работ по ГДП-200 были выявлены проявления керамических глин кайнозоя Нижнедевицкое и Ефросимовское.

Нижнедевицкое проявление расположено, в Нижнедевицком районе Воронежской области, в 1 км восточнее окраины д. Полянка. Полезная толща приурочена к отложениям киевской свиты эоцена и представлена глинами зеленовато-серыми, плотными, тяжелыми, пластичными. Породы толщи имеют пятнистую и полосчатую текстуры, подчеркнутые неравномерным ожелезнением, а также мелкими вкрапленниками углефицированной органики и омарганцеванием. Подстилается полезная толща мергелем объединенных терепшанской и подгоренской свит сантонского яруса верхнего отдела меловой системы; перекрывается - песками кантемировской свиты олигоцена. По минеральному составу глины иллитмонтмориллонит-каолинитовые. По содержанию глинозема $\left(\mathrm{Al}_{2} \mathrm{O}_{3}\right)$ они полукислые (14.17-17.0\%) и кислые (11.69-13.76\%), с высоким содержанием красящих оксидов $\mathrm{Fe}_{2} \mathrm{O}_{3}(3.00-5.6 \%)$ и $\mathrm{TiO}_{2}(0.89-1.61 \%)$. При обжиге дают персиковый цвет черепка. Мощность полезной толщи 5.4 м, вскрыши - 16 м.

Ефросимовское проявление расположено в Советском районе Курской области, в 4 км северовосточнее с. Ефросимовка. Здесь были вскрыты отложения нерасчлененных новопетровской и краснояружской свит миоцена. Полезная толща представлена глиной темно-серой, с пятнами охристого и малинового цвета, плотная. Содержание $\mathrm{Al}_{2} \mathrm{O}_{3}$ колеблется от 18.9 до $26.85 \%$, содержание красящих оксидов $\mathrm{Fe}_{2} \mathrm{O}_{3}-1.15-1.70 \%, \mathrm{TiO}_{2}-1.49-2.63 \%$. Мощность 8 м. Однако площадь распространения отложений новопетровской и краснояружской свит незначительна.

Для керамических глин кайнозоя минерагеническое районирование не проводилось, так как это сырье невысокого качества, месторождения рассредоточены по территории, а площади развития фаций незначительны. 


\section{Заключение}

Проведенные исследования позволили провести минерагеническое районирование керамических глин Воронежской антеклизы. Для каолинов ПКТ установлена Мамонская минерагеническая зона, включающая Павловск-Калачский минерагенический район. В нем выделен Воробьевский рудный узел, для которого подсчитаны прогнозные ресурсы по $\mathrm{P}_{3}$ в 7.8 млн т.

Выделенная для керамических глин аптского яруса Малоархангельск-Воронежская минерагеническая зона включает Воронежский и КурскоЕлецкий минерагенические районы. Первый является благоприятным для поисков огнеупорных разновидностей керамических глин. Он определен по распространению континентальных фаций, где в озерно-болотных условиях происходило «дозревание» вещества в условиях теплого гумидного климата при наличии значительного количества органического вещества. Курско-Елецкий район выделен по распространению лагунно-морских фаций. В пределах этого района вероятно обнаружение месторождений тугоплавких глин, т.к. глинистые минералы из пород лагунно-морской зоны имеют иллит-каолинитовый состав, унаследованный от размытых образований источников сноса. Он довольно выдержан практически на всей исследуемой территории.

В пределах Воронежского минерагенического района выделено четыре рудных узла, для которых подсчитаны прогнозные ресурсы по категории $\mathrm{P}_{3}$. В сумме они составляют 26.4 млн т. В пределах КурскоЕлецкого района подсчитанные прогнозные ресурсы керамических глин по категории $\mathrm{P}_{3}$ для двух рудных узлов составили 16.9 млн т. Для керамических глин кайнозоя районирование не проводилось из-за низкого качества сырья, сильной фациальной изменчивости и малой площади развития отложений.

Конфликт интересов: Автор декларирует отсутствие явных и потенциальных конфликтов интересов, связанных с публикацией настоящей статьи.

\section{ЛИТЕРАТУРА}

1. Савко А. Д., Крайнов А. В. Керамические глины Центрально-Черноземного района. Труды научноисследовательского института геологии: Воронеж, Изд-во Воронеж. гос. ун-та. Вып. 88. 2015. 109 с.

2. Крайнов А. В. Геология и минерагения керамических и огнеупорных глин аптского яруса Воронежской антеклизы: дис. ... канд. геол.-мин. наук. Москва, 2016. 132 с.

3. Bortnikov N. S., Mineeva R. M., Novikov V. M., Berketa A. G., Speranskii A. V., Savko A. D., Krainov A. V. Kaolinite history in the weathering crust and associated clay deposits: EPR data. Pleiades Publishing, Ltd. № 1. V. 433. Moscow. 2010. pp. 927-930.
4. Bortnikov N. S., Novikov V. M., Boeva N. M., Savko A. D., Krainov A. V., Dmitriev D. A., Zhegallo E. A., Bushueva E. B. Structural-morphological features of kaolinite from clayey rocks subjected to different stages of lithogenesis: evidence from the Voronezh anteclise // Lithology and mineral resource. 2013. №5. pp. 384-397.

5. Савко А. Д., Новиков В. М., Крайнов А. В., Давыдов Д. Н., Ратников В.Ю. Минерагения аптских отложений Воронежской антеклизы. Статья 1. Огнеупорные и керамические глины // Вестник Воронежского государственного университета. Серия: Геология. № 2. 2011. С. 116-136.

6. Крайнов А. В. Характеристика перспективных участков для постановки разведочных работ на керамические глины на границе Курской и Воронежской областей // Вестник Воронежского государственного университета. Серия: Геология.. 2015. № 3. С. 134-137.

7. Савко А. Д. Историческая геология: учебное пособие. Воронеж: Воронежский государственный университет, 2006. $450 \mathrm{c}$.

8. Металлогенический кодекс России. Москва, ГеокартГЕОС, 2012. $125 \mathrm{c}$.

9. Коробейников А. Ф., Кузебный В. С. Прогнозирование и поиски месторождений полезных ископаемых. Томск, 1998. $309 \mathrm{c}$.

10. Савко А. Д., Мануковский С. В., Шевырев Л. Т. Литология и полезные ископаемые мамонской песчано-каолиновой толщи Воронежской антеклизы. Труды научно-исследовательского института геологии: Воронеж, Изд-во Воронеж. гос. ун-та. Вып. 53. 2008. 112 с.

11. Савко А. Д., Мануковский С. В., Крайнов А. В., Корабельников Н. А., Милаш А. В. Вторичные каолины девона Воронежской антеклизы на примере месторождения Козынка // Вестник Воронежского государственного университета. Серия: Геология 2018. №. 2. С. 20-28

12. Савко А. Д. Огнеупорные глины и каолины Воронежской антеклизы // Генезис и ресурсы каолинов и огнеупорных глин. М: Наука, 1990. С. 35-47.

13. Крайнов А. В., Дмитриев Д. А. Керамические глины кайнозоя // Вестник Воронежского государственного университета. Серия: Геология. 2019. №. 2. С. 81-87.

14. Савко А. Д. Геология Воронежской антеклизы. Труды научно-исследовательского института геологии: Воронеж, Изд-во Воронеж. гос. ун-та. Вып. 12. 2002. 165 с.

15. Савко А. Д., Мануковский С. В., Мизин А. И., Бурыкин В. Н., Бартенев В. К. Объяснительная записка к атласу фациальных карт Воронежской антеклизы. Труды научноисследовательского института геологии: Воронеж, Изд-во Воронеж. гос. ун-та. Вып. 20. 2004. 107 с.

16. Холмовой Г. В., Савко А. Д., Дмитриев Д. А., Ратников В. Ю., Горюшкин В. В. Глины и условия их образования в неогене Воронежской антеклизы // Вестник Воронежского государственного университета. Серия: Геология. 2014. № 2. С. 30-35.

17. Холмовой Г. В. Неоген-четвертичный аллювий и полезные ископаемые бассейна Верхнего Дона. Воронеж, 1993. $99 \mathrm{c}$.

18. Холмовой Г. В. Верхний плиоцен бассейна Верхнего Дона. Воронеж, 1985. 137 с. 


\title{
Mineragenic zoning of ceramic clays of the Voronezh Anteclise
}

\author{
(C) 2020 A. V. Kraynov ${ }^{\bowtie}$, S. V. Manukovsky
}

Voronezh State University, 1 Universitetskaya pl., 394018 Voronezh, Russian Federation

\begin{abstract}
Introduction: In the territory of the Central Black Earth Economic Region, ceramic clays are valuable and at the same time scarce raw materials. They are confined to the deposits of the Mamon stratum of the upper Devonian, the Aptian tier of the lower Cretaceous, and the suites of the Kiev Eocene, the Berek Oligocene, the Shapkinskaya Miocene, and the Usman Pliocene. Clays of different age deposits differ in terms of formation, material composition and quality. Therefore, the question of the mineragenic zoning of ceramic clays is relevant.

Methodology: The solution to the problems of mineragenic zoning required the use of a variety of methods. Field studies, desk constructions of facial maps and sections, and laboratory and technological tests were carried out. Based on a comprehensive analysis of the data obtained, taxa for the regional mineragenic zoning in the ranks were identified: mineragenic (ore) zones, regions, and nodes. During the performed work, core samples of more than 50 wells were documented and tested, rocks from over 90 observation points (outcrops and quarries) were described and tested within the Voronezh, Kursk, Lipetsk, and Oryol regions. Samples were prepared and the mineral and chemical compositions of about 200 clay samples were studied using precision methods (diffractometric and electron microscopic methods).

Results and discussion: Ceramic clays of the Mamon stratum were formed in proluvial-deluvial and lakebog facies. From these, the Mamon mineragenic zone, including the Pavlovsk-Kalachsky region and the promising Vorobyovskaya area in the district has been identified. Ceramic clay is confined to the Aptian lacustrine-marshy and lacustrine-marine environments. Valuable refractory varieties were formed on land as a result of "flowing" diagenesis, high-melt varieties were formed during sedimentation. Differences in the formation conditions resulted in differences in the material composition and quality of clay raw materials. This allowed the identification of the Voronezh and Kursk-Yelets mineragenic regions. They are part of the Maloarkhangelsk-Voronezh mineragenic zone. The Voronezh mineragenic region corresponds to the distribution of continental facies. The Kursk-Yelets mineragenic region corresponds to the distribution of lagoon-marine facies. For the ceramic clays of the Cenozoic, mineragenic zoning was not carried out, since this raw material is of poor quality, the deposits are dispersed over the territory, and areas of facie development are insignificant.

Conclusions: For the first time, mineragenic taxa for different-aged ceramic clays were identified by the close-analogy method, and inferred resources were calculated. In total they amounted to 51.1 million tons in the $\mathrm{P}_{3}$ category.
\end{abstract}

Keywords: ceramic clays, mineragenic zone, region, node, Mamon stratum, Apt, Cenozoic.

For citation: Kraynov A.V., Manukovsky S.V., Mineragenic zoning of ceramic clays of the Voronezh Anteclise. Vestnik Voronezhskogo gosudarstvennogo universiteta. Seriya: Geologiya = Proceedings of Voronezh State University. Series: Geology, 2020, no. 1, pp. 66-77. DOI: https://doi.org/10.17308/geology. 2020.1/2515

Conflict of interests: The authors declare the absence of obvious and potential conflicts of interest related to the publication of this article.

The content is available under Creative Commons Attribution 4.0 License.

\footnotetext{
Alexey V. Kraynov, E-mail: aleksey_vsu_geo@mail.ru
} 


\section{REFERENCES}

1. Savko A. D, Kraynov A. V. Keramicheskie gliny CentralnoChernozemnogo rajona. [Ceramic clay Central Black Earth region]. Trudy Nauchno-issledovatel'skogo Instituta Geologii [The work of the Research Institute of Geology], Voronezh, VSU Publ. vol. 88, 2015. 109 p. (In Russ.)

2. Kraynov A. V. Geologiya i minerageniya keramicheskix i ogneupornyh glin aptskogo yarusa Voronezhskoj anteklizy: Diss. kand. geol.-min. nauk [Geology and minerageny of ceramic and refractory clays of the aptian stage of the Voronezh Anteclise PhD in Geol.-Min]. Moscow, 2016, 132 p.

3. Bortnikov N. S., Mineeva R. M., Novikov V. M., Berketa A. G., Speranskii A. V., Savko A. D., Krainov A. V. Kaolinite history in the weathering crust and associated clay deposits: EPR data. Pleiades Publishing, Ltd, no. 1, vol. 433, Moscow, 2010, pp. 927-930.

4. Bortnikov N. S., Novikov V. M., Boeva N. M., Savko A. D., Krainov A. V., Dmitriev D. A., Zhegallo E. A., Bushueva E. B. Structural-morphological features of kaolinite from clayey rocks subjected to different stages of lithogenesis: evidence from the Voronezh anteclise. Lithology and mineral resource, 2013, no. 5, pp. 384-397.

5. Savko A. D., Novikov V. M., Kraynov A. V., Davydov D. N., Ratnikov V.Yu. Minerageny of aptsk sediments of the Voronezh anteclise. Vestnik Voronezhskogo gosudarstvennogo universiteta. Seriya: Geologiya = Proceedings of Voronezh State University. Series: Geology, 2011, no. 2, pp. 116-136 (In Russ.)

6. Kraynov A. V. Characteristics of promising areas for exploration work on ceramic clay on the Kursk and Voronezh border areas. Vestnik Voronezhskogo gosudarstvennogo universiteta. Serija: Geologija = Proceedings of Voronezh State University. Series: Geology, 2015, no. 3, pp. 134-137 (In Russ.)

7. Savko A.D. Istoricheskaya geologiya: uchebnoe posobie [Historical geology: study guide]. Voronezh, 2006, 450 p. (In Russ.)

8. Metallogenic code of Russia. Moscow, Geokart GEOS, 2012, $125 \mathrm{p}$.

9. Korobejnikov A. F., Kuzebnyj V. S. Prognozirovanie $i$ poiski mestorozhdenij poleznyh iskopaemyh [Forecasting and prospecting for mineral deposits]. Tomsk, 1998, 309 p (In Russ.) 10. Savko A. D., Manukovskiy S. V., Shevyrev L. T. Litologiya i poleznye iskopaemye mamonskoj peschano-kaolinovoj tolshhi
Voronezhskoj anteklizy [Mamonskaya sandy-kaolinic suite of the Voronezh abteclise], Trudy Nauchno-issledovatel'skogo Instituta Geologii [The work of the Research Institute of Geology], Voronezh, VSU Publ. vol. 53, 2008, 112 p. (In Russ.)

11. Savko A. D., Manukovskij S. V., Kraynov A. V., Korabel`nikov N. A., Milash A. V. Secondary kaolins of the devon of the Voronezh anteclise by the example of the Kozynka deposit. Vestnik Voronezhskogo gosudarstvennogo universiteta. Seriya: Geologiya = Proceedings of Voronezh State University. Series: Geology, 2018, no. 2, pp. 20-28 (In Russ.)

12. Savko A. D. Ogneupornye gliny i kaoliny Voronezhskoj anteklizy. [Refractory clay and kaolin of Voronezh anteclise]. Genesis and resources of kaolins and refractory clays Moscow. Nauka, 1990, pp. 35-47.

13. Kraynov A. V., Dmitriev D. A. Cenozoic ceramic clay of the Central Black earth region. Vestnik Voronezhskogo gosudarstvennogo universiteta. Seriya: Geologiya = Proceedings of Voronezh State University. Series: Geology, 2019, no. 2, pp. 8187 (In Russ.)

14. Savko A. D. Geologiya Voronezhskoj anteklizy. [Geology of the Voronezh anteclise]. Trudy Nauchno-issledovatel'skogo Instituta Geologii [The work of the Research Institute of Geology], Voronezh, VSU Publ., vol. 12, 2002. 165 p. (In Russ.)

15. Savko A. D. Manukovskiy S. V., Mizin A. I., Burykin V. N., Bartenev V. K. Ob`yasnitel`naya zapiska $\mathrm{k}$ atlasu facial`nyh kart Voronezhskoj anteklizy. [Explanatory memorandum to the facies maps atlas of the Voronezh anteclise]. Trudy Nauchnoissledovatel'skogo Instituta Geologii [The work of the Research Institute of Geology], Voronezh, VSU Publ. vol. 20, 2004, 107 p. (In Russ.)

16. Holmovoy G. V., Savko A. D., Dmitriev D. A., Ratnikov V. N., Goryushkin V. V. Clays and conditions of their formation in the neogene of the Voronezh anteclise. Vestnik Voronezhskogo gosudarstvennogo universiteta. Seriya: Geologiya = Proceedings of Voronezh State University. Series: Geology, 2014, no. 2, pp. 30-35 (In Russ.)

17. Holmovoy G. V. Neogen-chetvertichnyj allyuvij i poleznye iskopaemye bassejna Verhnego Dona. [Neogene-Quaternary alluvium and minerals of the Upper Don basin]. Voronezh, 1993, 99 p. (In Russ.)

18. Holmovoy G. V. Verhnij pliocen bassejna Verhnego Dona. [Upper Pliocene of the Upper Don basin]. Voronezh, 1985, 137 p. (In Russ.)
Крайнов Алексей Владимирович - к. г.-м. н., доцент, Воронежский государственный университет, Воронеж, Российская федерация; E-mail: aleksey_vsu_geo@mail.ru; ORCID http://orcid.org/0000-0003-0038-0990

Мануковский Сергей Викторович - к. г.-м. н., старший научный сотрудник, НИИ Геологии, Воронежский государственный университет, Воронеж, Российская федерация; Еmail: manukovsky@inbox.ru;

ORCID http://orcid.org/0000-0002-1252-5344

Авторы прочитали и одобрили окончательный вариант рукописи.
Alexey V. Kraynov - PhD in Geol-Min., Associate Professor,

Voronezh State University, Voronezh, Russian Federation;

E-mail: aleksey_vsu_geo@mail.ru;

ORCID http://orcid.org/0000-0003-0038-0990

Sergey V. Manukovskiy - PhD in Geol-Min., research fellow, Research Institute of Geology, Voronezh State University, Voronezh, Russian Federation;

E-mail: manukovsky@inbox.ru;

ORCID http://orcid.org/0000-0002-1252-5344

All authors have read and approved the final manuscript. 